\title{
Active microbial ecosystem in Iron-Age tombs of the Etruscan civilization
}

Angela Cirigliano, ${ }^{a}$ Francesco Mura, ${ }^{b}$ Adele Cecchini, ${ }^{c}$ Maria Cristina Tomassetti, ${ }^{d}$ Daniele Federico Maras, ${ }^{e}$ Monica Di Paola, ${ }^{f}$ Niccolò Meriggi, ${ }^{f}$ Duccio Cavalieri, ${ }^{f}$ Rodolfo Negri, ${ }^{a}$ Andrea Quagliariello, ${ }^{\mathrm{g}}$ John Edward Hallsworth ${ }^{\mathrm{h} \#}$ and Teresa Rinaldia\#

aDepartment of Biology and Biotechnology, Sapienza University of Rome, 00185, Rome, Italy. ${ }^{\mathrm{b}}$ CNIS - Center for Nanotechnology Applied to Industry of La Sapienza, Sapienza University of Rome, 00185, Rome, Italy.

'Restorer, Associazione no profit "Amici delle tombe dipinte di Tarquinia", 01016, Tarquinia, taly.

${ }^{\mathrm{d}}$ Restorer-Conservator, Galleria Nazionale dell'Umbria, 06123, Perugia, Italy.

Archaeologist, Soprintendenza Archeologia Belle Arti e Paesaggio per l'Area Metropolitana di Roma, la Provincia di Viterbo e l'Etruria Meridionale, Ministero dei Beni e delle Attività Culturali e del Turismo, 00186, Rome, Italy.

Department of Biology, University of Florence, 50019, Firenze, Italy.

${ }^{9}$ Department of Comparative Biomedicine and Food Science, University of Padova, 35020, Padova, Italy.

"Institute for Global Food Security, School of Biological Sciences, Queen's University Belfast, 19 Chlorine Gardens, Belfast, BT9 7BL, UK.

fFor correspondence. E-mail j.hallsworth@qub.ac.uk; teresa.rinaldi@uniroma1.it

\section{ginality-significance statement}

This study provides insight into the modern microbiology of Iron-Age tombs of the Etruscan civilization in central Italy. These 2500-year-old underground rooms, excavated from stone, nave walls covered in ancient paintings with a patina formed of biogenic needles of $\mathrm{CaCO}_{3}$ 'moonmilk). Here, we report three highly intriguing findings:

- this environment hosts communities primarily bacteria that are mesophilic for both temperature tolerance and xerotolerance;

is populated by photosynthetic Cyanobacteria exhibiting a heterotrophic lifestyle; and

This article has been accepted for publication and undergone full peer review but has not been through the copyediting, typesetting, pagination and proofreading process which may lead to differences between this version and the Version of Record. Please cite this article as doi: 10.1111/14622920.15327 
- the precipitation of $\mathrm{CaCO}_{3}$ occurs on the surface indicating that it is biogenic (and thereby protecting, rather than degrading, the frescoes).

We also reveal:

- the ways in which microbiology impacts the mineralogy, and mineralogy determines the microbiology;

- occasional community members are psychrotolerant or resistant to ionizing radiation; and - provide insight into the time taken for biogenic formation of moonmilk - only 1 to 5 decades.

We discuss the paradox that these ecosystems that are for the most part in the dark so lack primary production yet appear to be highly active, biodiverse and biomass-rich

\section{Abstract}

Earth's microbial biosphere extends through the crust and much of the subsurface, including nicrobial ecosystems within cave systems. Here, we elucidate the microbial ecosystems within anthropogenic caves; the Iron-Age, subterranean tombs of central Italy. The interior walls of the rock (calcium-rich macco) were painted $\sim 2500$ years ago and are covered with $\mathrm{CaCO}_{3}$ needles (known as moonmilk). The aims were to: identify siological/geochemical/biophysical determinants of, and characterize bacterial communities involved in $\mathrm{CaCO}_{3}$ precipitation; challenge the maxim that biogenic activity necessarily degrades surfaces; locate the bacterial cells that are the source of the $\mathrm{CaCO}_{3}$; and gain insight into the kinetics of moonmilk formation. We reveal that this environment hosts communities that consist primarily of bacteria that are mesophilic for temperature and xerotolerance including Actinobacteria, Bacteroidetes and Proteobacteria); is populated by photosynthetic Cyanobacteria exhibiting heterotrophic nutrition (Calothrix and Chroococcidiopsis); and has $\mathrm{CaCO}_{3}$ precipitating on the rock surfaces (confirmation that this process is biogenic) that acts preserve rather than damage the painted surface. We also identified that some community members are psychrotolerant (Polaromonas), acidotolerant or acidophilic (members of the Acidobacteria), or resistant to ionizing radiation (Brevundimonas and Truepera); elucidate the Nays in which microbiology impacts mineralogy and vice versa; and reveal that biogenic formation of moonmilk can occur rapidly, i.e. from between 10 and 50 years. We discuss the paradox that these ecosystems that are for the most part in the dark so lack primary production, yet appear to be highly active, biodiverse and biomass-rich. 
Keywords: $\mathrm{CaCO}_{3}$ precipitation, cave ecosystem; Etruscan Iron-Age tombs, mesophiledominated microbial community, moonmilk formation, subsurface biosphere.

\section{Introduction}

Against a backdrop of climate change and deteriorating planetary health, our knowledge of Earth's biosphere is becoming increasingly more detailed and ever more important (Cavicchioli et al., 2019). Considerable advances have been made in our understanding of global biodiversity, the physicochemical and biophysical limits of our biosphere, uncultivatable taxa (microbial 'dark matter'), functions of the deep-subsurface ecosystems, and contributions of the planetary microbiome to environmental health. Whereas a considerable research effort las also focused on historical interactions between human cultures and the ecology of plants and animals, the co-existence and interactions between humans and microbes has received 'ess attention.

For several thousands of years, agriculture and other human activities have uransformed landscapes, modified geological processes, and destroyed or created habitats for plants and animals alike (Hanson et al., 2020; Rick and Sandweiss, 2020). Our domestication of crop plants and livestock is also well-documented, and it is also well-established that we have also (often without knowing) domesticated microbial taxa, such as Saccharomyces cerevisiae (Duan et al., 2018; Meriggi et al., 2020). But what is less-often appreciated is that the development of our civilizations, and our day-to-day activities, have created new habitats or microbes and, in this process, have created new microbial ecosystems.

Here, based on a well-preserved Iron-Age site, we elucidate the present-day microbiology of a unique underground system which lives in underground rooms excavated m $n$ bedrock between 2700 and 2200 years ago by the Etruscan peoples (central Italy). This is a calcium-rich rock known as macco; a form of calcarenite. Several studies by the some of the current authors have revealed that the microorganisms present in these tombs (Tarquinia, Jiterbo) are involved in the biogenic formation of nano-scale needles of $\mathrm{CaCO}_{3}$ (called noonmilk) that creates a patina on the interior walls and ceiling (Tomassetti et al., 2017; Cirigliano et al., 2018; Mura et al., 2020). Needles of $\mathrm{CaCO}_{3}$ are also known to form on surfaces within limestone caves (Cacchio et al., 2014), in other subterranean environments (Borsato et al., 2000; D'Angeli et al., 2019), and even within the Lewis Cliff 85311 meteorite (Lee et al., 2019). 
Moonmilk formation requires a complex interaction between geological and biological factors. The biogenic contribution to formation of the precipitate was proposed previously (Cañaveras et al., 2006; Cailleau et al., 2009; Baskar et al., 2011; Portillo and Gonzalez, 2011; Braissant et al., 2012; Rodriguez-Navarro et al., 2012): the bacterial communities that live in a calcium-rich environment (Banks et al., 2010). An extracellular alkaline pH and the presence of the calcium ions are stressful for bacteria because a passive calcium influx promotes a calcium/hydrogen electrochemical gradient leading to high intracellular calcium and excessive proton expulsion (Clapham, 1995; Hammes and Verstraete, 2002; Domínguez, 2018). Further, calcium is an essential messenger in cellular signaling so a sustained high concentration of intracellular $\mathrm{Ca}^{2+}$ can lead to cell death.

Bioprecipitation of $\mathrm{CaCO}_{3}$ is mediated by microbes via processes such as ureolysis; urease catalyzes the hydrolysis of urea into ammonium and carbonate. In this reaction, urea is hydrolyzed to ammonia and carbonate (carbamic acid), which is spontaneously hydrolyzed to produce carbonic acid $\left(\mathrm{H}_{2} \mathrm{CO}_{3}\right)$ and more ammonia $\left(\mathrm{NH}_{3}\right)$. In an aqueous milieu, carbonic acid and ammonia will reach equilibrium, forming bicarbonate ions and releasing hydroxide ons. The hydroxide ions result in an increase of $\mathrm{pH}$, resulting in the formation of carbonate ions. In turn, carbonate ions combine with calcium thereby precipitating and $\mathrm{CaCO}_{3}(\mathrm{Anbu}$ et al., 2016).

Deterioration of paintings on the walls of the Tarquinia tombs has occurred since the opening of the tombs, and this is likely due to a combination of the associated environmental changes, invasion by plant roots, and the activities of microorganisms (Caneva et al., 2020). The near-pristine condition of the paintings until this time indicates that relative humidity remained constant within the tombs over the millennia, from the Iron Age to their openingat end of the 18th Century. Since the tombs were opened, and until hermetically sealed doors were installed (this occurred from at various times between 1990 and the present day, depending on the tomb), they were subject to fluctuations caused by changes in ambient emperature and relative humidity for a period of almost 200 years. Once doors were installed, relative humidity remain constant, at about 95 to 98\% (Tomassetti et al., 2017). Whereas the ongoing formation of moonmilk provides evidence of microbial activity, we have little insight Into the composition and functionality of the underground ecosystem within these Tarquinia tombs. The specific aims of the current study were to: identify biological, geochemical and biophysical determinants of $\mathrm{CaCO}_{3}$ precipitation; characterize the bacterial communities in 
terms of their ecophysiological character and phylogeny; challenge the maxim that biogenic activity necessarily degrades ancient paint layer; locate the bacterial cells that are the source of the $\mathrm{CaCO}_{3}$ (moonmilk); and gain insight into the kinetics of moonmilk formation.

\section{Results and Discussion}

Determinants of $\mathrm{CaCO}_{3}$ precipitation (formation of moonmilk). Nine underground tombs of the Monterozzi Necropolis (Tarquinia) (Fig. 1) were selected for their diversity in terms of: geographic location; age; thickness of the moonmilk layer; presence/absence of a calciumrich layer of primer laid by the Etruscans prior to painting; and type of rock from which the ombs were excavated. Six tombs were excavated in macco, which is a yellow calcarenite formed in the Pliocene era. Three out of the nine tombs had been excavated in an area in which the macco is interrupted by a low-calcium bench called sabbione, an incoherent yellow sandstone with a fine grain size. Information on anthropogenic interventions since tomb discovery/opening is summarised in Experimental Procedures and Table 1. The walls of the nine tombs were sampled to carry out scanning electron microscopy (SEM) studies (Fig. S1) of the surface patina (Fig. S2). A layer of $\mathrm{CaCO}_{3}$ precipitate was present in each, but these layers ranged from millimeters to centimeters in depth depending on the tomb (Table 1). The crystals of which they were composed also varied in size and shape between tombs, from nano-scale needles to thicker, more irregular structures (Fig. S1).

According to culture-based studies carried out in vitro, bacterial cell walls and biofilms can act as nucleation sites for carbonate precipitation (Decho, 2010; Ercole et al., 2012). Here, we used SEM to look for evidence that this can occur in situ and thereby lead to the formation noonmilk. In the moonmilk samples from Tomba del Cardinale (Fig. 2A-D) and Tomba dei Vasi Dipinti (Fig. 2E-J), we found $\mathrm{CaCO}_{3}$ entrapping microbial structures. Upon energy dispersive spectroscopy (EDX) analysis, they appeared to be entombments of a filamentous vacterium (Fig. S3). Similar microbes were present in the Tomba del Vecchio (Fig. 2K and -.).In the Tomba del Cardinale, Tomba dei Vasi Dipinti and Tomba del Vecchio, the nanofibers originated from the entrapped microbes (Fig. 2B, E, L, red arrows), and SEM analysis of these revealed the presence of biofilms (Fig. 2B, G and I, pink arrows). Whereas diverse lines of evidence indicate that the $\mathrm{CaCO}_{3}$ precipitate of these tombs is (in part at least) of biotic origin, it is difficult to ascertain the relative contributions of biogenic and abiotic processes. The 
precipitation of $\mathrm{CaCO}_{3}$ is influenced by the following factors: calcium concentration in the environment, amount of dissolved inorganic carbon, availability of nucleation sites, and $\mathrm{pH}$ (Hammes and Verstraete, 2002). In relation to the role of bacteria in this process, there are three key factors: the mineralization occurs as a consequence of cellular metabolism; carbonate nucleation takes place on the cell wall; and the matrix of extracellular polymeric secretions (EPS) in biofilms accelerates $\mathrm{CaCO}_{3}$ precipitation, allowing bacteria to sequester calcium ions to produce $\mathrm{CaCO}_{3}$ in a high-pH environment (Ercole et al., 2007; Marvasi et al., 2012; Kim and Roh, 2019). The precipitation of carbonates by bacteria is the result of one or more metabolic process(es), such as photosynthesis, reduction of sulfates, and urea nydrolysis (Dhami et al., 2018). Therefore, the microbial communities in the tombs live in zonditions that favour the formation of moonmilk (Sanchez-Moral et al., 2012; Maciejewska et ঐl., 2017; Mauran et al., 2019).

The Etruscan people coated the interior walls with a calcium-rich preparatory layer a few millimeters thick as a primer, on top of which a coloured paint layer, also based on a mixture of lime and macco, was applied (Table 1; Fig. S2). The primer (lime mixed with ground macco) was present in most tombs but absent from Tomba dei Leoni Rossi and Tomba delle Pantere. Nevertheless, thick moonmilk formations $(0.5$ to $2 \mathrm{~cm})$ were observed in these two tombs (as well as four of the others). Furthermore, precipitated $\mathrm{CaCO}_{3}$ was found on tomb ceilings, where (a) primer- and/or paint layer(s) were usually absent, so neither calcium-rich primer not calcium-rich paint was a prerequisite for moonmilk formation.

Whereas temperature and relative humidity can influence $\mathrm{CaCO}_{3}$ precipitation, the neasured values (see Experimental Procedures) were between 16 and $18^{\circ} \mathrm{C}$ and 95 and $98 \%$, respectively; values known to be optimal for the formation of moonmilk (Leuko et al., 2017). T n nba del Cardinale, Tomba dell'Orco and Tomba degli Scudi are located in close proximity to each other and characterised by thinner layers of moonmilk relative to the other tombs (Fig. 1; Table 1). The macco in the area of these three tombs is interrupted by sabbione (D'Agostino et al., 2010; Cecchini et al., 2012). Even though primer did not appear to promote extensive noonmilk formation (maybe it was too thin to provide enough calcium to have a measurable impact), the sabbione was apparently so calcium-poor as to constraint the precipitation of $\mathrm{CaCO}_{3}$, because the moonmilk layers here were only $0.1 \mathrm{~mm}$ in thickness (Table 1 ).

Moonmilk deposits were not present in tombs of the Etruscan necropolises of Sarteano (Siena) (Pallecchi et al., 2009) and Cerveteri (Rome) (Alfeld et al., 2018). However, these 
tombs were excavated from travertine (a limestone) and tuffs (formed from volcanic ash), respectively. In the Etruscan necropolis in Chiusi (Siena), the Tomba del Colle and Tomba della Scimmia, where the paint layer was applied on top of a thin clay primer, were excavated from weakly cemented sands with intercalations of clay layers and pebble beds. In these tombs, microbial growth was associated with $\mathrm{CaCO}_{3}$ deposits of calcite crystals (2- to 4-mm in size) but nanometric needle fibers of calcite were not observed by SEM analysis (DiazHerraiz et al., 2013; Diaz-Herraiz et al., 2014). These observations confirm that moonmilk formation in Tarqunia is influenced by the geochemistry of the bedrock.

Kinetics of formation of $\mathrm{CaCO}_{3}$-needles. The kinetics of moonmilk formation have not been lefinitely determined, and questions remain about the time-period required for production of $\mathrm{CaCO}_{3}$ nanorods. To date, only one study reported the formation of moonmilk deposits on a imescale of < 50 years; on an artificial wall constructed around 1940-50 in the Altamira cave (Cañaveras et al., 1999). The periodic restoration activity within some of the tombs (during which moonmilk is removed) provides a valuable opportunity to study the dynamics of fresh noonmilk formation. The Tomba Bartoccini, Tomba delle Sculture and Tomba dei Vasi Dipinti proved useful to determine a time period necessary for moonmilk deposition. This is because during the restoration of the Tomba Bartoccini, when the restorers removed the moonmilk from he walls, graffiti dating from the Middle Ages was revealed, indicating that the overlaying moonmilk was produced after the use of this tomb by Templars (in 1260 A.C.) (Cataldi and Micozzi, 2012); the northern-east wall of Tomba delle Sculture was initially restored in 2008 (Fig. S4A), the restoration was resumed and completed in 2014 and the 2-cm thick moonmilk layer was completely removed (Fig. S4B), in 2018, a very thin patina in the lower part of the thern-east wall (Fig. S4B, blue arrow) was observed and then analysed by SEM revealing the presence of moonmilk indicating that it was produced after the 2008 restoration (Fig. S4C and D); and in 1963, the Tomba dei Vasi Dipinti was vandalised and portions of the walls with nural paintings were removed (Fig. S5A and B) (Cecchini et al., 2012). SEM analysis of samples from this deposit revealed the presence of nanometric rods of $\mathrm{CaCO}_{3}$ (observed in 2019, see Fig. S5C-F), indicating that moonmilk formation in Tomba dei Vasi Dipinti occurred within the last 56 years (i.e. since 1963). The results demonstrated that a new deposition of the moonmilk is possible in a relatively short period of time; i.e., as short as 10 years in the Tomba delle Sculture. 
Subterranean tombs that are highly permissive for life. From an anthropocentric perspective, the underground tombs of the Monterozzi Necropolis, devoid of light for more than two millennia and associated with the burial of human corpses, may seem somewhat less than welcoming. To microorganisms, however, rock surfaces, cave environments, and the Earth's crust present diverse and habitable and fertile niches. Whereas there has often been a tendency to take an anthropocentric view of microbial environments (Cavicchioli et al., 2019), the prevailing temperatures and relative humidity values within the tombs under study (see above) are very permissive for microbes that are mesophilic in relation to temperature and water activity (Rummel et al., 2014; Stevenson et al., 2015a; Stevenson et al., 2015b; Lee et l., 2018), and on this basis cannot be considered very extreme for microbes.

With the aim to determine whether a common bacterial core is present in the moonmilk, the bacterial communities in four representative tombs (Tomba Bartoccini, Tomba dei Leoni Rossi, Tomba delle Pantere and Tomba delle Sculture) were analyzed along with the results already obtained from Tomba degli Scudi (Cirigliano et al., 2018). The results of the 16S rRNA amplicon sequencing showed the presence of Actinobacteria and Proteobacteria as the most abundant phyla (Fig. 3A).

16S RNA analyses do not provide information about metabolic activity (Portillo et al., 2009), so these data do not identify microorganisms active in $\mathrm{CaCO}_{3}$ deposition. The $16 \mathrm{~S}$ rRNA amplicon sequencing of Tomba Bartoccini, Tomba dei Leoni Rossi, Tomba delle Jantere, Tomba degli Scudi and Tomba delle Sculture revealed a high bacterial biodiversity. This variability was highlighted in the Bray-Curtis analysis (Fig. S6A), where sites were divided by the first axis. Tomba Bartoccini and Tomba delle Sculture clustered together, indicating ilarity in their microbiota. Tomba dei Leoni Rossi and Tomba delle Pantere clustered closely along the first and second axes, suggesting the presence of shared traits. Tomba degli Scudi appears to be an outlier in relation to the other sites analyzed. Tomba Bartoccini and Гomba delle Sculture were both characterized by higher Observed- and Shannon index values than the other three tombs, suggesting higher species richness (Fig. S6B). This distribution of the $\beta$-diversity data indicated a higher relative abundance of Cyanobacteria in Tomba Bartoccini and Tomba delle Sculture samples with respect to Tomba delle Pantere and Tomba dei Leoni Rossi. The two latter tombs were characterized by a higher relative abundance of Proteobacteria, while the microbial community of Tomba degli Scudi showed a higher relative 
abundance of SBR1093 and Acidobacteria, Ellin6075 family, and it is also characterized by the absence of Cyanobacteria (Fig. 3A). The primer pair used in this study can also amplify archaea (Wasimuddin et al., 2020) and we found Crenarchaeota and Euryarchaeota in Tomba degli Scudi (Fig. 3A). The phylum Bacteroidetes was well represented in the Tomba dei Leoni Rossi and Tomba delle Pantere by Pedobacter, a soil-associated genus (Fig. 3B). Halophilic Bacteroidetes species can be associated with subsurface stone monuments (Piñar et al., 2014).

The microbiomes were analysed to identify common microbial taxa in the Tomba Bartoccini, Tomba dei Leoni Rossi, Tomba delle Pantere, Tomba degli Scudi and Tomba delle Sculture. Setting a microbiome profile threshold of $80 \%$ of total reads, the phyla Acidobacteria Actinobacteria, Bacteroidetes, Cyanobacteria and Proteobacteria were common to the nicrobiomes of all five tombs. The microbiome analyses at the genus level revealed that Deinococcus, Hylemonella, Lysobacter and Sphingomonas were present in all five tombs. In addition to these genera, the five tombs also hosted (unidentified) genera from the families Nocardioidaceae, Ellin6075, Sphingobacteriaceae and Oxalobacteraceae and from the orders Rhizobiales and Rhodospirillales (Table S2). At the threshold of $80 \%$ of total reads, the genera Deinococcus and Sphingomonas and were abundant across Tomba Bartoccini, Tomba dei Leoni Rossi, Tomba delle Pantere and Tomba delle Sculture. These genera are also commonly detected in stone microbial communities (Brewer and Fierer, 2018; Louati et al., 2019).

These results showed that the majority of taxa present within the tombs appear to exhibit mesophilic phenotypes in relation to their tolerance to both temperature and water activity/ xerotolerance. For example, Actinobacteria and Proteobacteria (Fig. 3A; Table S2).

iguingly, however, we did identify several microbes known to have robust capabilities in terms of their stress biology. Most notably, we found:

- a psychrophilic genus, Polaromonas, that is wel- represented in Tomba degli Scudi and has Jeen found in a limestone cave located in Arizona (Kartchner Cavern) (Darcy et al., 2011; Ortiz et al., 2013);

- members of the Acidobacteria, some of which are known to be acidotolerant or acidophilic; and

microbes resistant to ionizing radiation included Brevundimonas, which is the second mostabundant genus in Tomba delle Pantere, and Truepera, which is the fifth most-abundant genus 
in Tomba Bartoccini (also present in Tomba delle Sculture) (Brewer and Fierer, 2018; Louati et al., 2019).

The unique microbial community found in the Tomba degli Scudi (different from those of Tomba Bartoccini, Tomba dei Leoni Rossi, Tomba delle Pantere and Tomba delle Sculture) is determined by the calcium content of the rock, $\mathrm{pH}$, and/or the proportion of the mineral substrate consisting of sand particles (though these factors that are not necessarily mutually exclusive). This observation may also explain the presence of a thin moonmilk layer in this tomb and in the Tomba del Cardinale and Tomba dell'Orco.

It is interesting to note that Tomba dei Leoni Rossi and Tomba delle Pantere, which nost a very similar microbial community, are in close proximity to each other (Fig. 1) and that leither has a primer layer. Further, Tomba Bartoccini and Tomba delle Sculture host similar nicrobial communities, and they are also situated in proximity to each other (Fig. 1); in this case, each has a primer layer. These observations suggest that even if the primer was not the main determinant of moonmilk thickness, it nevertheless does contribute to microbial community composition, almost certainly by providing calcium.

Bacterial genera present in moonmilk are usually found within the epilithic and endolithic microbial communities of the macco and sabbione (Zhou et al., 2007; Antony et al., 2012; Chan et al., 2012; Mogul et al., 2017). The fissures in calcite rocks facilitate ingress of water which in turn supports the proliferation of microorganisms (Meslier and DiRuggiero, 2019). Moreover, chasmoendolitic bacteria, which colonize cracks and fissure in calcite rock DiRuggiero et al., 2013), belong to the same phyla known to be present in moonmilk. The dominant bacterial phyla in subsurface sedimentary habitats - Actinobacteria, Chloroflexi, Firmicutes, Planctomyces and Proteobacteria (Gaboyer et al., 2019).

Evidence of subterranean Cyanobacteria. There was an abundance of Cyanobacteria in the Tomba Bartoccini and Tomba delle Sculture (Fig. 3A and B; Table S1). A lower amount Nas also present in the Tomba dei Leoni Rossi and Tomba delle Pantere, and none in the Tomba degli Scudi, but which did contain two orders of the sister phylum Melainabacteria (SM1D11 and MLE1-12), albeit at low percentages (Table S1). Melainabacteria, previously classified as Cyanobacteria, produce energy through fermentation and the release hydrogen gas that can be consumed by other microorganisms and are not able to perform photosynthesis (Di Rienzi et al., 2013; Soo et al., 2014). Nostocaceae and Rivulariaceae 
(Calotrix) were detected only in the Tomba Bartoccini (Table S1), and this can be explained by the use of light-emitting diodes (LED) white lights during tourist visits (see Experimental Procedures). The Cyanobacteria populations in the Tomba delle Sculture, situated in close proximity to the Tomba Bartoccini, must subsist heterotrophically because these tombs are not equipped with artificial lights so are always dark. The microbial families found in the tombs are Xenococcaceae (genus Chroococcidiopsis) and the Rivulariaceae (genus Calothrix). The Chroococcidiopsis is the most-abundant genus in Tomba Bartoccini (11,56\% of total reads), and in Tomba delle Sculture (20.9\% of total reads), able to grow in harsh environmental conditions, including both high and low temperatures (desiccated cells of Chroococcidiopsis sp. survive to $90^{\circ} \mathrm{C}$, hydrated cells above $60^{\circ} \mathrm{C}$ ), high doses of ionizing radiation (up to $15 \mathrm{kGy}$ ) and high salinity (Billi et al., 2000; Hauer et al., 2015; Lacap-Bugler et al., 2017). We know that some Cyanobacteria can adopt a heterotrophic lifestyle. However, there is a paucity of studies about heterotrophic nutrition of Chroococcidiopsis in complete darkness, Chroococcidiopsis and Calothix accounted for $80 \%$ of total reads in deep subsurface rock samples (from 392- to 613-m deep) in Spain (Puente-Sánchez et al., 2018) and in oxic subseafloor sediment millions Jf years old in a metabolically active form (Morono et al., 2020). Calothrix, present in Tomba Bartoccini, Tomba dei Leoni Rossi and Tomba delle Sculture inhabits caves where it switches to heterotrophic metabolism in the complete darkness (Whitton, 1987). It is intriguing to wonder whether it is the autotrophic or heterotrophic metabolism of such taxa evolved first.

In the Etruscan tombs, the following Cyanobacteria genera were also found (albeit at jery low abundance): Toxopsis, usually present in cave environments (Haurer et al., 2015); Pleurocapsa and Phormidium, also found in the Frasassi Caves (Giordano et al., 2000); Acaryochloris, known in Antarctic granite rocks (De Los Ríos et al., 2007); and Leptolyngbya

Scytonema, previously reported in Roman and Maltese hypogea (Bellezza et al., 2003; Zammit et al., 2011). It was recently shown that Cyanobacteria producing chlorophyll $d$ and $f$ (Leptolyngbya and Acaryochloris spp.) were present limestone caves, in complete darkness. These bacteria can photosynthesize using near-infrared radiation and chlorophyll $d$ and $f$ to generate energy (Behrendt et al., 2020). A future study on the presence of Cyanobacteria capable of utilising near-infrared radiation in the tombs devoid of visible light is needed to elucidate their potential contribution to moonmilk metabolism. 
Mineral precipitation occurs at the very surface, indicating that it is biogenic. Macco is a porous rock, and it would be expected that $\mathrm{CaCO}_{3}$ precipitate would occur both within and on the surface of the rock matrix if the process was geochemically driven. However, we observed that the moonmilk deposit only formed at the microbial layer; i.e. on the very surface of the walls and ceiling and (where they are present) on top of the primer- and paint layers. This was both noteworthy and remarkable because endolithic bacteria also produce moonmilk within macco (T. Rinaldi, unpublished data) and are generally known to accelerate the deterioration and discoloration of monuments and buildings (Scheerer et al., 2009). Cyanobacteria degrade/weather the rock surface (Cockell and Herrera, 2008; Bruno and Valle, 2017), and Actinobacteria induce biomineralization and pigment production (Sterflinger and Piñar, 2013; Sakr et al., 2020). However, in the current study, the $\mathrm{CaCO}_{3}$ acted to protect the Etruscan paintings because it occurred where the microbes are (Fig. 4). This observation vas also consistent with the biogenic nature of the precipitation process.

\section{Concluding remarks}

The current study provided insight into the geomicrobiology of moonmilk formation on the surface of calcareous rock. It also highlights the way in which human interventions can inadvertently transform microbial ecosystems that have been stable for millennia. This environment is dominated by microbial mesophiles, but does include some highly stresstolerant taxa. We also found that some tombs are dominated by the Cyanobacteria $\mathrm{The}^{\mathrm{CaCO}} 3$ jrecipitate, that can form more rapidly than we had expected (in as little as 10 years), can ossilize microbial cells, so is reminiscent of some microbialites and stromatolites. The microbial biosphere is by definition organic, so seems generally more fragile than the Earth's ith osphere. However, the intimate interactions that can take place between biosphere and lithosphere underline the fact that, in reality, neither is independent of the other.

The Etruscan tombs were apparently well preserved for more than two millennia, likely due to high and constant relative humidity that sustained microbial activity. Interestingly, we found no trace of halophilic or other xerophilic genera, but this may not be surprising given that the humidity levels have been high for millennia. Indeed, the biologically permissive relative-humidity range (95-98\%) and the moderate temperature range (16 to $\left.18^{\circ} \mathrm{C}\right)$ favour active microbial communities composed primarily of mesophilic species (i.e. those that are not thermophilic, psychrophilic, xerophilic or halophilic). This said, further work is needed using 
isolation media containing high concentrations of glycerol or $\mathrm{NaCl}$ to select for obligate xerophiles and halophiles, respectively. Most of the taxa identified as present are known to function optimally in the mesophile temperature range and at high water-activity values: above 0.900 (equivalent to relative humidity values of more than $90 \%$ ) (Stevenson et al., 2015b). The biogenic precipitation of $\mathrm{CaCO}_{3}$ acted to stabilize primer- and paint layers, but environmental alterations induced by opening up the tombs (fluctuations of temperature and relative humidity), and the deliberate removal of moonmilk, caused microbiome-driven changes over the past 200 years, underlining the fragility of these semi-natural structures. The ecosystems that we attempted to reconstruct during the current study are a combined product of microberock relations in the context of ancient and modern anthropogenic involvement activities. We ind it somewhat reassuring that, despite human interventions, microorganisms carry on "egardless.

\section{Experimental procedures}

Description of the Monterozzi Necropolis of Tarquinia (Viterbo, Italy).

The Tomba Bartoccini, Tomba del Cardinale, Tomba dei Leoni Rossi, Tomba dell'Orco, Tomba delle Pantere, Tomba degli Scudi, Tomba delle Sculture, Tomba dei Vasi Dipinti and Tomba del Vecchio were chosen for this study (Fig. 1; Table 1) to represent the Etruscan painted tombs based on the criteria listed in Results and Discussion. Tomba Bartoccini, Tomba dei Leoni Rossi, Tomba delle Pantere, Tomba delle Sculture, Tomba del Vecchio, Tomba dei Jasi Dipinti were carved in macco. Tomba del Cardinale, Tomba dell'Orco and Tomba degli Scudi are situated in close proximity (Fig. 1) and were carved in sabbione. Each of these tombs is now protected by hermetic doors (Fig. S7) with no artificial lights, and closed to the hlic with the exception of Tomba Bartoccini which is open to the public and visitors can switch on lights for a short period of time and see the mural paintings through the glass of the door. All fieldwork was carried out under the supervision of Soprintendenza Archeologia, Belle Arti e Paesaggio.

\section{Sample collection}

Moonmilk deposits were collected from the nine tombs of the Monterozzi Necropolis using sterile scalpels (about 0,5 g) and kept in $10 \mathrm{ml}$ sterile tubes (Fig. S8). Samples for SEM were analyzed within 24 hours of collection. Moonmilk samples ( 0.2 to $0.3 \mathrm{~g}$ ) from Tomba Bartoccini, 
Tomba dei Leoni Rossi, Tomba delle Pantere and Tomba delle Sculture (Fig. S8E and F) were processed immediately for microbial community analysis, as used previously (Cirigliano et al., 2018). At the time of this study, the Tomba Bartoccini, Tomba delle Pantere and Tomba delle Sculture had been restored and the moonmilk was completely removed except for a $5 \mathrm{~cm}^{2}$ area that had been deliberately left by the restorers for future analysis. For this reason, and due to the archaeological importance of this site, we were allowed to analyze only one sample from each tomb (Fig. S8).

\section{Scanning electron microscopy and microanalysis}

SEM micrographs were performed using a Field Emission Scanning Electron Microscopy (FESEM) Zeiss Auriga 405, with a chamber room that maintains a pressure of about $10^{-5}-10^{-}$ mbar. Before mounting the samples inside the microscope, the specimens were coated with $20 \mathrm{~nm}$ of chromium using a Quorum Q150T sputter. Chromium has a high X-ray Ka value (5.145 keV), so does not interfere with lighter elements during the EDX analysis. EDX spectra were obtained using a Bruker Quantax detector in point mode for 30 seconds, with the electron microscope parameters acceleration voltage $10 \mathrm{kV}$ and working distance $6 \mathrm{~mm}$ to optimize the number of the incoming X-ray signal.

\section{Environmental parameters}

An automatic in-situ monitoring system for measuring temperature and relative humidity (Data logger LASCAR, EL-USB-2 LCD) was installed in the Tomba degli Scudi (Cirigliano et al., 2018). Between March and December 2017, in the Tomba degli Scudi the relative humidity vas in the range $95-98 \%$ and the temperature was $16^{\circ} \mathrm{C}$. It was not possible for us to measure eıvironmental parameters in the remaining eight tombs studied here due to access estrictions. Thus, data from these eight tombs were obtained from the restorers using published (Bettini and Massa, 1991) or unpublished datasets collected during the restoration of the tombs' paintings (Adele Cecchini, personal communication). The temperature in the ombs typically varied between $16-18^{\circ} \mathrm{C}$ during the summer months, but reached $20^{\circ} \mathrm{C}$ in Tomba dei Vasi Dipinti, Tomba del Vecchio and Tomba delle Pantere (Table 1).

DNA extraction, 16S rRNA gene sequencing and analysis 
Total DNA was extracted from the samples obtained from Tomba Bartoccini, Tomba dei Leoni Rossi, Tomba delle Pantere, and Tomba delle Sculture using DNeasy PowerSoil Pro Kit (QIAGEN, Milano, Italy), following the manufacturer's protocol. The quality of extracted DNA was checked with $1.5 \% \mathrm{w} / \mathrm{v}$ agarose gel electrophoresis. DNA concentration (ng/ $\mathrm{ll}$ ) was measured using Qubit ${ }^{\mathrm{TM}} 4$ Fluorometer and the dsDNA HS Assay Kit (Thermo Fisher Scientific, Milan, Italy).

PCR amplification of 16S rRNA genes was performed using a KAPA HiFi HotStart ReadyMix (Roche, Diagnostics SpA, Monza MB, Italy). This was carried out for the V3-V4 hypervariable regions of $16 \mathrm{~S}$ rRNA and using the following primers 341F (5'CCTACGGGNGGCWGCAG-3') and 805R (5'-GACTACNVGGGTWTCTAATCC-3') Klindworth et al., 2013). The standard protocol was followed according to the 16S netagenomic sequencing library preparation guide from Illumina (Illumina, 2013). Briefly, each DNA sample was amplified by PCR using $12.5 \mu \mathrm{l}$ of 2x KAPA HiFi HotStart ReadyMix, $10 \mu \mathrm{l}$ forward and reverse primers $(1 \mu \mathrm{M})$ and $2.5 \mu \mathrm{l}$ of template DNA (5-20 ng/ $\mu \mathrm{l})$, for a final $25 \mu \mathrm{l}$ of reaction solution. PCR products were purified using KAPA Pure Beads (Kapa Biosystems .nc., Roche Diagnostics SpA, Monza MB, Italy) and the subsequent dual indices and Illumina sequencing adapters. Indexing was performed using Nextera XT Index Kit V2 (Illumina). The amplicon library, after purification using KAPA Pure Beads (Roche), were checked using a Agilent 2100 Bioanalyzer (Agilent Technologies, Santa Clara, CA, USA) and Agilent DNA 1000 Kit, and quantified using a Quant-iT PicoGreen dsDNA Assay Kit (Thermo Fisher Scientific, Milano, Italy). After equimolar concentration checking, the bar-coded libraries were sequenced using Illumina MiSeq platform at Department of Biology, University of Florence, Italy. All the reads from Tomba Bartoccini, Tomba dei Leoni Rossi, Tomba delle Pantere, Tomba degli ' Idi and Tomba delle Sculture, were analyzed for their purity, sequence length, error rate and presence of chimeras, following the procedures developed by Callahan and colleagues (Callahan et al., 2016). The raw sequencing data from the Tomba degli Scudi samples eported in a previous study (Cirigliano et al., 2018) were retrieved and analyzed pooled with the data generated during the current study. The product of this analysis is an amplicon sequence variant table, characterized by higher resolution rate than classical operational taxonomic units (OTU) table. The sequences were deposited in the NCBI BioProject database under the accession number ID PRJNA625423. 
Taxonomy identification was performed using the naïve Bayesian classifier method (Wang et al., 2007) using Silva as the reference database. Once obtained, the amplicon sequence variant table, taxonomic identification, and phylogenetic trees were merged into a phyloseq object (McMurdie and Holmes, 2014) and analyzed for their ecological composition trough R software 3.6.0 version. For alpha diversity analysis, both Observed and Shannon indices were applied, while Bray-Curtis dissimilarity was calculated to draw PCoA for betadiversity analysis.

\section{ACKNOWLEDGEMENTS}

The authors would like to thank the Center of Nanotechnology Applied to The Engineering of Jniversity La Sapienza (CNIS) for the SEM analysis. We thank Beatrice Casocavallo 'Ministero dei Beni e delle Attività Culturali e del Turismo, Rome, Italy), Rosa Santomartino (University of Edinburgh, United Kingdom) and Orfelio Tortolini (Italy) for discussion of archeology, biology and geology, respectively. T.R. would like to thank Nicoletta Rinaldi (France) for sharing her knowledge on cultural heritage and restoration and Laura Frontali for constant support in exploring new applications of biology.

This work is dedicated in memory of archeologist Maria Donatella Gentili (University of Tor Vergata, Italy).

\section{REFERENCES}

A'feld, M., Baraldi, C., Gamberini, M. C., and Walter, P. (2018) Investigation of the pigment use in the Tomb of the Reliefs and other tombs in the Etruscan Banditaccia Necropolis. Xray cnectrom. 48: 262-273.

A lbu, P., Kang, C., Shin, Y., and So, J. S. (2016) Formations of calcium carbonate minerals by bacteria and its multiple applications. SpringerPlus 5: 250

Antony, C. P., Cockell, C. S., and Shouche, Y. S. (2012) Life in (and on) the rocks. J. Biosci. 37: 3-11.

Banks, E. D., Taylor, N. M., Gulley, J., Lubbers, B. R., Giarrizzo, J. G., Bullen, H. A., Hoehler, T. M., and Barton, H. A. (2010) Bacterial calcium carbonate precipitation in cave environments: a function of calcium homeostasis. Geomicrobiol. J. 27:5 444-454. 
Baskar, S., Baskar, R., and Routh, J. (2011) Biogenic evidences of moonmilk deposition in the Mawmluh Cave, Meghalaya, India. Geomicrobiol. J. 28:3 252-265.

Behrendt, L., Trampe, E. L., Nord, N. B., Nguyen, J., Kühl, M., Lonco, D., et al. (2020) Life in the dark: far-red absorbing cyanobacteria extend photic zones deep into terrestrial caves. Environ. Microbiol. 22:3 952-963.

Bellezza, S., Paradossi, G., De Philippis, R., and Albertano, P. (2003) Leptolyngbya strains from Roman hypogea: cytochemical and physico-chemical characterisation of exopolysaccharides. J. Appl. Phycol. 15: 193-200.

Bettini, G., and Massa, S. (1991) Preservation problems, visitors and deterioration on the painted Etruscan tomb. In: Science, Technology, and European Cultural Heritage. Baer, N. 5., Sabbioni, C., Sors, A. I. (eds). Butterworth-Heinemann Publishers: Guildford, Surrey. 761-769.

n'lli, D., Friedmann, E. I., Hofer, K. G., Caiola, M. G., and Ocampo-Friedmann, R. (2000) 'onizing-radiation resistance in the desiccation-tolerant cyanobacterium Chroococcidiopsis. Appl. Environ. Microbiol. 66:4 1489-1492.

Borsato, A., Frisia, S., Jones, B., and Van Der Borg K. (2000) Calcite moonmilk: crystal morphology and environment of formation in caves in the Italian Alps. J. Sediment. Ris. 70:5 1171-1182.

raissant, O., Bindschedler, S., Daniels, A. U., Verrecchia, E. P., and Cailleau, G. (2012) Microbiological activities in moonmilk monitored using isothermal microcalorimetry (Cave of Vers Chez Le Brandt, Neuchatel, Switzerland). J. Caves Karst Stud. 74:1 116-126.

Brewer, T. E., and Fierer, N. (2018) Tales from the tomb: the microbial ecology of exposed rock surfaces. Environ. Microbiol. 20:3 958-970.

runo, L., and Valle, V. (2017) Effect of white and monochromatic lights on cyanobacteria and 'jiofilms from Roman Catacombs. Int. Biodeter. Biodegr. 123:7 286-295.

acchio, P., Ferrini, G., Ercole, C., Del Gallo, M., and Lepidi, A. (2014) Biogenicity and characterization of moonmilk in the Grotta Nera (Majella National Park, Abruzzi, central Italy). J. Caves Karst Stud. 76:2 88-103. 
Cailleau, G., Verrecchia, E. P., Braissant, O., and Emmnuel, L. (2009) The biogenic origin of needle fibre calcite. Sedimentology 56:6 1858-1875.

Callahan, B. J., Sankaran, K., Fukuyama, J. A., McMurdie, P. J., and Holmes, S. P. (2016) Bioconductor workflow for microbiome data analysis: from raw reads to community analyses. F1000Research 5: 1492.

Cañaveras, J. C., Hoyos, M., Sanchez-Moral, S., Sanz-Rubio, E., Bedoya, J., Soler, V., et al. (1999) Microbial communities associated with hydromagnesite and needle-fiber aragonite deposits in a karstic cave (Altamira, Northern Spain). Geomicrobiol. J. 16:1 9-25.

Cañaveras, J. C., Cuezva, S., Sanchez-Moral, S., Lario, J., Laiz, L., Gonzalez, J.M., SaizJimenez, C. (2006) On the origin of fiber calcite crystals in moonmilk deposits. Sci. Nat. 93:1 27-32.

Caneva, G., Isola, D., Lee, H. J. and Chung, J. Y. (2020) Biological risk for hypogea: shared data from Etruscan tombs in Italy and ancient tombs of the Baekje dynasty in Republic of 'Korea. Appl. Sci. 10:17 6104.

Cataldi, M., and Micozzi, M. (2012) La Tomba Bartoccini e la necropoli di Tarquinia tra epoca etrusca e riscoperta umanistica. In: Graffiti templari. Scritture e Simboli Medievali in una Tomba Etrusca di Tarquinia. Tedeschi C. (eds). Viella. Rome, Italy.

Cavicchioli, R., Ripple, W. J., Timmis, K. N., Farooq A., Lars R. B., Matthew B., et al. (2019) Scientists' warning to humanity: microorganisms and climate change. Nat. Rev. Microbiol. 17: $569-586$.

Cecchini, A., Adamo, F., Buranelli, F., and Cataldi, M. (2012) Le Tombe dipinte di Tarquinia: vicenda conservativa, restauri, tecnica di esecuzione. Nardini Editore. Florence, Italy.

Chan, Y., Lacap, D. C., Lau, M. C., Ha, K. Y., Warren-Rhodes, K. A., Cockell, C. S., et al. (2012) Hypolithic microbial communities: between a rock and a hard place. Environ. Microbiol. 14:9 2272-2282.

Círigliano, A., Tomassetti, M. C., Di Pietro, M., Mura, F., Maneschi, M. L., Gentili, M. D., et al. (2018) Calcite moonmilk of microbial origin in the Etruscan Tomba degli Scudi in Tarquinia, Italy. Sci. Rep. 8:15839. 
Clapham, D. E. (1995) Calcium signaling. Cell 80:2 259-268.

Cockell, C. S., and Herrera, A. (2008) Why are some microorganisms boring? Trends Microbiol. 16:3 101-106.

D’Agostino, S., Lombardi, G., Russo, G., and Viggiani, C. (2010) Structural engineering and geology applied to the static problems of the Etruscan "Tomba dell'Orco" (Tarquinia, Central Italy). J. Cult. Herit. 11: 107-112.

D’Angeli, I. M., Ghezzi, D., Leuko, S., Firrincieli, A., Parise, M., Fiorucci, A., et al. (2019) Geomicrobiology of a seawater-influenced active sulfuric acid cave. PLoS One 14:8 e0220706.

Darcy, J. L., Lynch, R. C., King, A. J., Robeson, M. S., and Schmidt, S. K. (2011) Global distribution of Polaromonas phylotypes-evidence for a highly successful dispersal capacity. PLoS One 6:8 e23742.

ve Los Ríos, A., Grube, M., Sancho, L. G., and Ascaso, C. (2007) Ultrastructural and genetic characteristics of endolithic cyanobacterial biofilms colonizing Antarctic granite rocks. FEMS Microbiol. Ecol. 59:2 386-395.

Decho, A. W. (2010) Overview of biopolymer-induced mineralization: What goes on in hiofilms? Ecol. Eng. 36:2 137-144.

Dhami, N. K., Mukherjee, A., and Watkin, E. L. (2018) Microbial diversity and mineralogicalmechanical properties of calcitic cave speleothems in natural and in vitro biomineralization conditions. Front. Microbiol. 9: 40.

enzi, S. C., Sharon, I., Wrighton, K. C., Koren, O., Hug, L. A., Thomas, B.C., et al. (2013) The human gut and groundwater harbor non-photosynthetic bacteria belonging to a new candidate phylum sibling to Cyanobacteria. Elife 2: e01102.

Diaz-Herraiz, M., Jurado, V., Cuezva, S., Laiz, L., Pallecchi, P., Tiano, P., et al. (2013) The actinobacterial colonization of Etruscan paintings. Sci. Rep. 3: 1440.

Liaz-Herraiz, M., Jurado, V., Cuezva, S., Laiz, L., Pallecchi, P., Tiano, P., et al. (2014)

Deterioration of an Etruscan tomb by bacteria from the order Rhizobiales. Sci. Rep. 4: 3610. 
DiRuggiero, J., Wierzchos, J., Robinson, C. K., Souterre, T., Ravel, J., Artieda, O., et al. (2013) Microbial colonisation of chasmoendolithic habitats in the hyper-arid zone of the Atacama Desert. Biogeosciences 10:4 2439.

Domínguez, D. C. (2018). Calcium signaling in prokaryotes. In: Calcium Signal Transduction. IntechOpen. London, United Kingdom. 89-106.

Duan, S. F., Han, P. J., Wang, Q. M., Liu, W. Q., Shi, J. Y., Li, K., et al. (2018) The origin and adaptive evolution of domesticated populations of yeast from Far East Asia. Nat. Commun. ग: 1-13.

Ercole, C., Cacchio, P., Botta, A. L., Centi, V., and Lepidi, A. (2007) Bacterially induced mineralization of calcium carbonate: the role of exopolysaccharides and capsular jolysaccharides. Microsc. Microanal. 13:1 42-50.

Ercole, C., Bozzelli, P., Altieri, F., Cacchio, P., and Del Gallo, M. (2012) Calcium carbonate nineralization: involvement of extracellular polymeric materials isolated from calcifying jacteria. Microsc. Microanal. 18:4 829-839.

Gaboyer, F., Burgaud, G., and Edgcomb, V. (2019) The deep subseafloor and biosignatures. In: Biosignatures for Astrobiology. Cavalazzi, B., Westall, F. (eds). Springer. Berlin, Germany. 87-109.

Giordano, M., Mobili, F., Pezzoni, V., Hein, M. K., and Davis, J. S. (2000) Photosynthesis in the caves of Frasassi (Italy). Phycologia 39:5 384-389.

Hammes, F., and Verstraete, W. (2002) Key roles of pH and calcium metabolism in microbial carbonate precipitation. Rev. Environ. Sci. Bio. 1: 3-7.

Hanson, J. O., Rhodes, J. R., Butchart, S. H. M. et al. (2020) Global conservation of species' niches. Nature 580: 232-234.

Hauer, T., Mühlsteinová, R., Bohunická, M., Kaštovský, J., and Mareš, J. (2015) Diversity of syanobacteria on rock surfaces. Biodivers. Conserv. 24: 759-779.

.m, Y., and Roh, Y. (2019) Microbially induced carbonate precipitation using microorganisms enriched from calcareous materials in marine environments and their metabolites. Minerals 9: 722 . 
Klindworth, A., Pruesse, E., Schweer, T., Peplies, J., Quast, C., Horn, M., and Glöckner, F. O. (2013) Evaluation of general 16S ribosomal RNA gene PCR primers for classical and nextgeneration sequencing-based diversity studies. Nucleic Acids Res. 41:1 e1-e1.

Illumina, I. (2013). 16S Metagenomic sequencing library preparation. Preparing 16S Ribosomal RNA Gene Amplicons for the Illumina MiSeq System, 1-28. Part no. 15044223 Rev B. Illumina, San Diego, CA. https:// www.illumina.com.

Lacap-Bugler, D. C., Lee, K. K., Archer, S., Gillman, L. N., Lau, M. C., Leuzinger, S., et al. (2017) Global diversity of desert hypolithic cyanobacteria. Front. Microbiol. 8: 867.

Lee, C. J., McMullan, P. E., O'Kane, C. J., Stevenson, A., Santos, I. C., Roy, C., et al. (2018) $\mathrm{NaCl}$-saturated brines are thermodynamically moderate, rather than extreme, microbial labitats. FEMS Microbiol. Rev. 42:5 672-693.

Lee, M. R., Cohen, B. E., King, A. J., and Greenwood, R. C. (2019) The diversity of CM carbonaceous chondrite parent bodies explored using Lewis Cliff 85311. Geochim. Cosmochim. Acta. 264: 224-244.

Leuko, S., Koskinen, K., Sanna, L., D’Angeli, I. M., De Waele, J., Marcia, P., et al. (2017) The influence of human exploration on the microbial community structure and ammonia oxidizing potential of the Su Bentu limestone cave in Sardinia, Italy. PLoS One 12:7 e0180700.

Louati, M., Ennis, N. J., Ghodhbane-Gtari, F., Hezbri, K., Sevigny, J. L., Fahnestock, M. F., et al. (2019) Elucidating the ecological networks in stone-dwelling microbiomes. Environ. Microbiol. 22:4 1467-1480.

Maciejewska, M., Adam, D., Naômé, A., Martinet, L., Tenconi, E., Całusińska, M., et al. (2017) Assessment of the potential role of Streptomyces in cave moonmilk formation. Front. Microbiol. 8: 1181.

arvasi, M., Gallagher, K. L., Martinez, L. C., Molina Pagan, W. C., Rodríguez Santiago, R. E., Castilloveitía Vega, G., and Visscher, P. T. (2012) Importance of B4 medium in determining organomineralization potential of bacterial environmental isolates. Geomicrobiol. J. 29:10 916-924. 
Mauran, G., Bassel, L., Ferrier, C., Lacanette, D., Bousquet, B., and Chapoulie, R. (2019) Variability and sampling strategy of cave wall concretion: case study of the moonmilk found in Leye Cave (Dordogne). Archaeometry 61: 327-341.

McMurdie, P. J., and Holmes, S. (2014) Waste not, want not: why rarefying microbiome data is statistically inadmissible. PLoS Comput. Biol. 10:4 e1003531.

Meslier, V., and DiRuggiero, J. (2019) Endolithic microbial communities as model systems for ecology and astrobiology. In: Model Ecosystems in Extreme Environments. Academic Press. Cambridge, Massachusetts. 145-168.

Meriggi, N., Cavalieri, D., and Stefanini, I. (2020) Saccharomyces cerevisiae - insects association: impacts, biogeography, and extent. Front. Microbiol. 11: 1629.

Mogul, R., Vaishampayan, P., Bashir, M., McKay, C. P., Schubert, K., Bornaccorsi, R., et al. (2017) Microbial community and biochemical dynamics of biological soil crusts across a gradient of surface coverage in the Central Mojave Desert. Front. Microbiol. 8: 1974.

orono, Y., Ito, M., Hoshino, T., Terada, T., Hori, T., Ikehara, M., et al. (2020) Aerobic microbial life persists in oxic marine sediment as old as 101.5 million years. Nat.

Commun. 11: 1-9.

Nura, F., Cirigliano, A., Bracciale, M. P., and Rinaldi, T. (2020) Characterization of nanostructured calcium carbonate founded in two ancient Etruscan tombs. AIP Conference Proceedings. Rome, Italy. 2257: 020011.

Ortiz, M., Neilson, J. W., Nelson, W. M., Legatzki, A., Byrne, A., Yu, Y., et al. (2013). Profiling bacterial diversity and taxonomic composition on speleothem surfaces in Kartchner Caverns, AZ. Microb. Ecol. 65:2 371-383.

Pallecchi, P., Giachi, G., Colombini, M. P., Modugno, F., and Ribechini, E. (2009) The painting of the Etruscan "tomba della Quadriga Infernale" (4th century BC), in Sarteano (Siena, Italy): echnical features. J. Archaeol. Sci. 36: 2635-2642.

Diñar, G. K. Sterflinger, and Ettenauer, J. (2014) La vie en rose: a review of the rosy discoloration of subsurface monuments. In: The Conservation of Subterranean Cultural 
Heritage. Saiz-Jimenez, C. (eds). Taylor and Francis Group. Oxfordshire, United Kingdom. 113-124.

Portillo, M. C., Saiz-Jimenez, C., and Gonzalez, J. M. (2009) Molecular characterization of total and metabolically active bacterial communities of "white colonizations" in the Altamira Cave, Spain. Res. Microbiol.160:1 41-47.

Portillo, M. C., and Gonzalez, J. M. (2011) Moonmilk deposits originate from specific bacterial communities in Altamira Cave (Spain). Microb. Ecol. 61: 182-189.

Puente-Sánchez, F., Arce-Rodríguez, A., Oggerin, M., García-Villadangos, M., Moreno-Paz, M., Blanco, Y., et al. (2018) Viable cyanobacteria in the deep continental subsurface. Proc. vatl. Acad. Sci. USA. 115:42 10702-10707.

Rick, T. C., and Sandweiss, D. H. (2020) Archaeology, climate, and global change in the age of humans. Proc. Natl. Acad. Sci. USA. 117:15 8250-8253.

rrodriguez-Navarro, C., Jroundi, F., Schiro, M., Ruiz-Agudo, E., and González-Muñoz, M. T. (2012) Influence of substrate mineralogy on bacterial mineralization of calcium carbonate: implications for stone conservation. Appl. Environ. Microbiol. 78:11 4017-4029.

Rummel, J. D., Beaty, D. W., Jones, M. A., Bakermans, C., Barlow, N. G., Boston, P. J., et al. 2014) A new analysis of Mars "special regions": findings of the second MEPAG special regions science analysis group (SR-SAG2). Astrobiology 14:11 887-968.

Sakr, A. A., Ghaly, M. F., Edwards, H. G. M., Ali, M. F. and Abdel-Haliem, M. E. (2020) Involvement of Streptomyces in the deterioration of cultural heritage materials through biomineralization and bio-pigment production pathways: a review. Geomicrobiol. J. 37:7 110.

Sanchez-Moral, S., Portillo, M. C., Janices, I., Cuezva, S., Fernandez-Cortes, A., Cañaveras, J. C., and Gonzalez, J. M. (2012) The role of microorganisms in the formation of calcitic noonmilk deposits and speleothems in Altamira cave. Geomorphology 139: 285-292.

cheerer, S., Ortega-Morales, O., and Gaylarde, C. (2009) Microbial deterioration of stone monuments-an updated overview. Adv. Appl. Microbiol. 66: 97-139. 
Soo, R. M., Skennerton, C. T., Sekiguchi, Y., Imelfort, M., Paech, S. J., Dennis, P. G., et al. (2014) An expanded genomic representation of the phylum cyanobacteria. Genome Biol. Evol. 6:5 1031-1045.

Sterflinger, K., and Piñar, G. (2013) Microbial deterioration of cultural heritage and works of art-tilting at windmills? Appl. Microbiol. Biotechnol. 97:22 9637-9646.

Stevenson, A., Cray, J. A., Williams, J. P., Santos, R., Sahay, R., Neuenkirchen, N., et al. (2015a) Is there a common water-activity limit for the three domains of life? ISME J. 9:6 1333-1351.

Stevenson, A., Burkhardt, J., Cockell, C. S., Cray, J. A., Dijksterhuis, J., Fox-Powell, M., et al. (2015b) Multiplication of microbes below 0.690 water activity: implications for terrestrial and extraterrestrial life. Environ. Microbiol. 17:2 257-277.

I omassetti, M. C., Cirigliano, A., Arrighi, C., Negri, R., Mura, F., Maneschi, M. L., et al. (2017) A role for microbial selection in frescoes' deterioration in Tomba degli Scudi in Tarquinia, taly. Sci. Rep. 7: 6027.

Wang, Q., Garrity, G. M., Tiedje, J. M., and Cole, J. R. (2007) Naive Bayesian classifier for rapid assignment of rRNA sequences into the new bacterial taxonomy. Appl. Environ. Microbiol. 73:16 5261-5267.

Wasimuddin, W., Schlaeppi, K., Ronchi, F., Leib, S. L., Erb, M., and Ramette, A. (2020) Evaluation of primer pairs for microbiome profiling across a food chain from soils to humans within the One Health framework. Mol. Ecol. Resour. 00:1-14.

Whitton, B. A. (1987) "The biology of Rivulariaceae". In: The cyanobacteria: a comprehensive review. Fay P. and Van Baale C. (eds). Elsevier Science Ltd. 13-534.

Zammit, G., Billi, D., Shubert, E., Kastovsky, J., and Albertano, P. (2011) The biodiversity of subaerophytic phototrophic biofilms from Maltese hypogea. Fottea 11:1 187-201.

ıou, J., Gu, Y., Zou, C., and Mo, M. (2007) Phylogenetic diversity of bacteria in an earthsave in Guizhou Province, Southwest of China. J. Microbiol. 45:2 105-112. 
Conflict of Interest Statement: The authors declare that the research was conducted in the absence of any commercial or financial relationships that could be construed as a potential conflict of interest. 


\section{Figures legends}

Fig. 1. Map of the Necropolis of Tarquinia showing (red dots) the Tomba Bartoccini (42.249536, 11.771456), Tomba del Cardinale (42.248172, 11.778390), Tomba dell'Orco (42.246699, 11.780554), Tomba dei Leoni Rossi (42.240358, 11.794708), Tomba delle Pantere (42.241378, 11.791685), Tomba degli Scudi (42.247597, 11.777425), Tomba delle Sculture (42.248050, 11.770867), Tomba dei Vasi Dipinti (42.246032, 11.784392), Tomba del Vecchio (42.246022, 11.784386).

Fig. 2. Scanning electron micrographs of a bacteria entombed in moonmilk samples: Tomba del Cardinale (A-D); Tomba dei Vasi Dipinti (E-J); and Tomba del Vecchio (K; L). In (J), the blue arrow indicates where the analysis shown in Fig. S3 was performed. In pictures (B, G) and (I), pink arrows indicate biofilms. Red arrows indicate calcite nanofibers originated from he entombed microbes.

تig. 3. Phyla present in the microbial community from moonmilk samples of Tomba Bartoccini, Tomba dei Leoni Rossi, Tomba delle Pantere, Tomba degli Scudi, and Tomba delle Sculture. Community structure was determined by targeted amplicon sequencing of bacterial 16S rRNA yenes. All samples show a high abundance of Actinobacteria, Bacteroidetes, Cyanobacteria and Proteobacteria $(\mathbf{A})$; heatmap representing the bacteria genera in the microbial community from moonmilk samples of Tomba Bartoccini, Tomba dei Leoni Rossi, Tomba delle Pantere, Tomba degli Scudi, and Tomba delle Sculture with a relative abundance higher than $0.5 \%$. The increasing intensity of the red colouration indicates a higher abundance of taxa (B). Distances have been calculated using Bray-Curtis method and were represented using hclust (see Experimental procedures).

Fig. 4. The east wall of the Tomba degli Scudi atrium before (A) and after restoration work carried out in 2016-2017 (B). Prior to restoration, it was thought that microbial activity may nave damaged the primer- and paint layers $(\mathbf{A})$, but removal of moonmilk revealed that the $\mathrm{CaCO}_{3}$ precipitate had actually protected the underlying surface (B). White arrows indicate changes/damage to the paint layer due to condensation of water or other abiogenic processes.

rable 1. Characteristics of the Etruscan tombs in which microbiology and $\mathrm{CaCO}_{3}$ precipitation were studied. 
$\$$
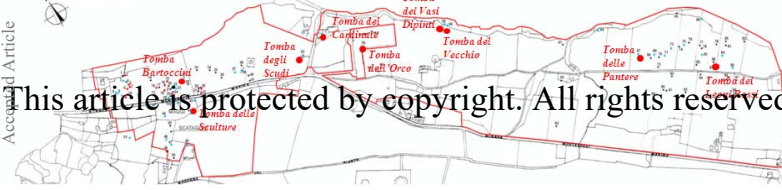
All rights reserved. 


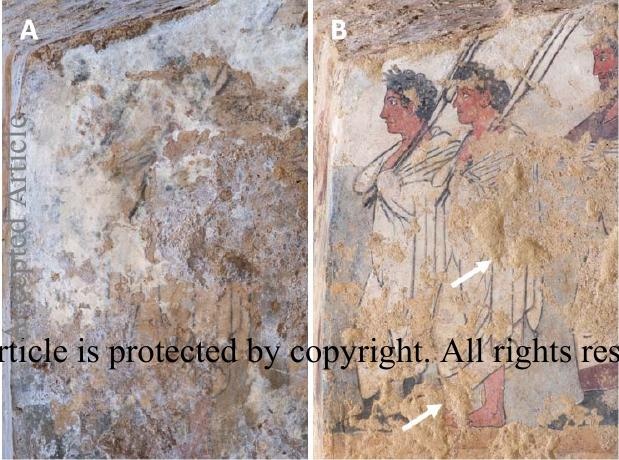


Table 1. Characteristics of the Etruscan tombs in which microbiology and $\mathrm{CaCO}_{3}$ precipitation were studied.

\begin{tabular}{|c|c|c|c|c|c|}
\hline Name & $\begin{array}{l}\text { Parent } \\
\text { rock }\end{array}$ & $\begin{array}{l}\text { Distance of } \\
\text { the tomb } \\
\text { ceiling } \\
\text { below } \\
\text { ground level } \\
\text { (m) }\end{array}$ & $\begin{array}{l}\text { Presence/absent } \\
\text { of a preparatory } \\
\text { layer (primer) on } \\
\text { the rock surface }\end{array}$ & $\begin{array}{c}\text { Time of } \\
\text { construction }\end{array}$ & $\begin{array}{l}\text { Thickness of } \\
\text { CaCO }_{3} \\
\text { precipitate }(\mathrm{cm})\end{array}$ \\
\hline $\begin{array}{c}\text { Tomba } \\
\text { Bartoccini }\end{array}$ & Macco & 3 & Present $^{a}$ & $\begin{array}{l}530 \text { to } 520 \\
\text { B.C. }\end{array}$ & 0.5 to 1 \\
\hline $\begin{array}{l}\text { Tomba del } \\
\text { Cardinale }\end{array}$ & Sabbione & 10 & Present $^{b}$ & $\begin{array}{l}298 \text { to } 210 \\
\text { B.C. }\end{array}$ & 0.1 \\
\hline $\begin{array}{l}\text { Tomba dei } \\
\text { Leoni Rossi }\end{array}$ & Macco & 2.5 & Absent $^{\mathrm{d}}$ & $\begin{array}{l}530 \text { to } 520 \\
\text { B.C. }\end{array}$ & 1 \\
\hline Tomba dell'Orco I & Sabbione & 10 & Present $^{\mathrm{C}}$ & $\begin{array}{l}530 \text { to } 510 \\
\text { B.C. }\end{array}$ & 0.1 \\
\hline $\begin{array}{c}\text { Tomba delle } \\
\text { Pantere }\end{array}$ & Macco & 2 & Absent $^{\mathrm{d}}$ & $\begin{array}{l}620 \text { to } 610 \\
\text { B.C. }\end{array}$ & 1.5 to 2 \\
\hline $\begin{array}{l}\text { Tomba degli } \\
\text { Scudi }\end{array}$ & Sabbione & 10 & Present $^{\mathrm{D}}$ & 340 B.C. & 0.1 to 0.2 \\
\hline
\end{tabular}




\begin{tabular}{|c|l|c|c|c|c|}
\hline $\begin{array}{c}\text { Tomba delle } \\
\text { Sculture }\end{array}$ & Macco & 1 & Present $^{\mathrm{b}}$ & $\begin{array}{c}290 \text { to } 250 \\
\text { B.C. }\end{array}$ & 1.5 to 2 \\
\hline $\begin{array}{c}\text { Tomba dei Vasi } \\
\text { Dipinti }\end{array}$ & Macco & 1.5 & Present $^{\mathrm{a}}$ & $\begin{array}{c}530 \text { to } 510 \\
\text { B.C. }\end{array}$ & 0.5 \\
\hline $\begin{array}{c}\text { Tomba del } \\
\text { Vecchio }\end{array}$ & Macco & 1.5 & Present $^{\mathrm{a}}$ & $\begin{array}{c}530 \text { to } 510 \\
\text { B.C. }\end{array}$ & 0.5 \\
\hline
\end{tabular}

a. Prior to the application of a paint layer, the surface was prepared by applying a layer of plaster made from powdered lime, clay, and water.

b. Prior to the application of a paint layer, the surface was prepared by applying a layer of plaster made from powdered lime, powdered macco, and water.

c. Prior to the application of a paint layer, the surface was prepared by applying a layer of plaster made from powdered lime, silicate sand, and water.

d. In this case, paint was applied directly onto the rock surface. 